\title{
EXPECTATIONS OF SERVICE RECIPIENTS TOWARD THE SERVICE OF UDON THANI HOSPITAL
}

\author{
Jakkapat Siriprasoet ${ }^{1}$ \\ Faculty of Business Administration and Accountancy, Khon Kaen University (KKU), Thailand. \\ (Email: earthhinata@gmail.com) \\ Associate Professor Dr. Nitipol Phutachote ${ }^{2}$ \\ Faculty of Business Administration and Accountancy, Khon Kaen University (KKU), Thailand. \\ (Email: nitput@kku.ac.th) \\ Associate Professor Dr. Pensri Jaroenwanit ${ }^{3}$ \\ Faculty of Business Administration and Accountancy, Khon Kaen University (KKU), Thailand. \\ (Email: penjar@kku.ac.th)
}

Received date: $21-02-2019$

Revised date: 04-03-2019

Accepted date: $29-08-2019$

Published date: 15-09-2019

To cite this document: Jakkapat, S., Nitipol, P., \& Pensri J. (2019). Expectations of Service Recipients Towards the Service of Udon Thani Hospital. International Journal of Entrepreneurship and Management Practices, 2 (7), 13-18.

DOI: $10.35631 /$ ijemp.27002

\begin{abstract}
The results showed that most respondents were female. They are between the ages of 41-50 years old and have a bachelor's degree or higher. Have average income between 10,00120,000 baht engaged in agricultural work and live in the district of Udon Thani. Analyzes of expectations before services and service satisfaction of service recipients toward the service of Udon Thani hospital. (Service Quality) It was found that the service recipients had significantly different expectations and service satisfaction number 3 sides. Service Receiver have expectations in most assurance, followed by empathy and tangibles respectively. However, when the service is completed, the service recipients are satisfied with the service side in most assurance followed by empathy and tangibles respectively. To sum up, comparing the actual expectations and satisfaction of the service, it was found that service recipients are more satisfied than expected 1 item: assurance. Finally, the empathy and the tangible things, service recipients have greater expectations than service satisfaction.
\end{abstract}

Keywords: Expectations, Service Satisfaction, Services

\section{Introduction}

Ministry of Public Health Establish a national health insurance policy to provide people with access to a health care system. Quality and standards are equal. Udon Thani Hospital has seen the need for sanitation and medical care of the people of Udon Thani. However, Udon Thani Hospital is still experiencing the problem of higher number of patients. This has resulted in delays, congestion and limited service personnel. The fatigue of the service providers affects the quality of service, resulting in the public not understanding and dissatisfaction with the medical service. From the above reasons. Researchers were aware of the importance of clients 
who came to Udon Thani Hospital. Therefore, they are interested in the quality of service and the expectation of service recipients on the service of Udon Thani Hospital. The results of the research were developed and formulated as a guideline to reinforce the strengths and weaknesses of Udon Thani Hospital.

Quality of service is different from sales. Due to the quality of the intangible, variability, inseparability and perish ability. Therefore, service recipients are influenced by expectations for service come from 4 major sources. Personal Needs, Word of Mouth Communication, Past Experience, External Communications to Customer and the measure of hope and perception of consumers related to the quality of services. There are 5 main components used to create a quality measurement of service include tangibles, reliability, responsiveness, assurance and empathy.

\section{Research Objectives}

1. To study the expectation and service quality of the service recipients towards the service of Udon Thani Hospital.

2 . To compare the expectations and quality of services of the service recipients with the services of Udon Thani Hospital by demographic factors.

\section{Research Scope}

Exploratory Research this is quantitative research. The research instrument was a questionnaire. The study population was the outpatient department (OPD) of the Udon Thani hospital. The study population was the relatives of the patients who were admitted to Udon Thani hospital.

\section{Literature Review}

Literature review on service quality. Zeithaml, Parasuraman, and Berry (1990) The study found that the results of customer evaluation of the quality of customer service is called perceived service quality. This is because the customer makes a comparison expected service. It is an experience that occurs after the customer has been served already. Evaluation of service quality ( SERVQUAL) the customer considers the following five important criteria as follows: reliability, assurance, tangibles, empathy and responsiveness.

\section{Research Method}

Samples were relatives who took patients to Udon Thani Hospital used 384 people. For the convenience of evaluation. And data analysis. The researcher used 400 samples. It is considered that the criteria. Is not less than 384 people. By calculating the Taro Yamane formula at a $95 \%$ confidence level and determining the tolerable error of .05 , the researchers used a selection of non-probability samples. By choosing a convenient sample. The sample will be studied for ease of study. It is convenient to provide information.

The research instrument was closed-ended questionnaire, divided into 2 parts:

Part 1 Checklist.The questionnaire on demographic data of respondents included gender, age, educational level, average income, occupation, and domicile.

Part 2 was a questionnaire about the expectation of service recipients on the service of Udon Thani Hospital include: tangibles, reliability, responsiveness, assurance and empathy. 


\section{Steps to Create A Research Tool}

Researchers have set guidelines for creating research tools. To obtain the following objectives:

1. Research papers, texts, articles, websites and related documents.

2. Create a query to consult with the advisors to check and receive suggestions for improvement in accordance with research.

3. Take the revised questionnaire to the advisor for review before completing the test.

4. The questionnaire was used to determine the reliability of data. The sample was used to try out the sample of 30 samples. The reliability of the questionnaire (Conbach's Alpha Coefficient) in this study was the reliability of the questionnaire of .892 .

5. Take the tested and edited questionnaire. The sample size was 400 samples.

\section{Statistics Used in Data Analysis}

Once the data has been collected completely. The researcher will use the data to code. Use SPSS for Windows to calculate statistics. To use the data analysis.

Descriptive Analysis Used for distribution of frequency, word, percentage, average and standard deviation. To use in describing the questionnaire. Is the demographic information.

Inferential Statistics are statistics used to test hypotheses in research to summarize references to population studied. The data in the questionnaire about the level of expectation and the level of service received. The statistics used to test the relationship between factors. Use the Independent Sample T-Test to compare the difference between the mean of two groups and one-way analysis of variance or F-test samples with more than 2 groups. If found significant differences were found at .05 level. The double difference was tested by LSD (Least Significant Difference) and use a statistical test Pair-sample t-test to compare the expectation and actual service of the service recipients to Udon Thani Hospital.

\section{Research Result}

\section{Facts About Demographic Factors}

Answerer The sample size was 400. Most of them were female between 41-50 years old with bachelor degree or higher. Have an average income 10,001-20,000 baht engaged in agricultural work and in the district of Udon Thani.

\section{The Hypothesis Testing}

Different demographic factors affect expectations of service recipients toward the service of Udon Thani hospital different. There are only 4 aspects of demographic factors that accept the hypothesis.

1. Service recipients of different ages have expectations to the services of Udon Thani Hospital differed significantly at the .05 level and when classified as a couple on average, service recipients over 41-50 years of age were more likely to expect services from Udon thani hospital than those aged 31-40.

2. Service recipients have different levels of education have expectations and perceptions were statistically significantly different at the .05 level. When classified in pairs found that on average, service recipients with bachelor's degree or higher have expectation of service of Udon thani hospital was higher than the level of education diploma. However, in terms of average perceived service recipients with bachelor's degree, the satisfaction of the service of Udon Thani Hospital was lower service recipients with high school education. 
3. Service recipients have different occupations have expectations to the services of Udon Thani Hospital differed significantly at the .05 level and when classified as a couple on average, service recipients are already employed have expectations for service of Udon Thani hospital were higher than those of students.

4. Service recipients with different domiciles have perception was significantly different at .05 level and found that service recipients who live outside Udon Thani area are more satisfied with service than those who live in Udon Thani.

\section{Conclusions of The Comparison of Expectations and Services Received}

\begin{tabular}{|c|c|c|c|c|c|c|}
\hline \multirow{2}{*}{ Variable } & \multicolumn{2}{|c|}{ Expectations } & \multicolumn{2}{|c|}{$\begin{array}{l}\text { services } \\
\text { received }\end{array}$} & \multirow{2}{*}{$\mathbf{t}$} & \multirow{2}{*}{ Sig. } \\
\hline & $\bar{X}$ & $S D$ & $\bar{X}$ & $S D$ & & \\
\hline 1. Tangibles & 3.80 & 0.53 & 3.46 & 0.53 & 10.86 & $.00 *$ \\
\hline 2. Reliability & 4.17 & 0.53 & 4.19 & 0.56 & -0.58 & .56 \\
\hline 3. Responsiveness & 3.74 & 0.57 & 3.68 & 0.55 & 1.90 & .06 \\
\hline 4. Assurance & 4.16 & 0.49 & 4.24 & 0.52 & -2.58 & $.01 *$ \\
\hline 5. Empathy & 3.92 & 0.56 & 3.63 & 0.64 & 7.55 & $.00 *$ \\
\hline Total & 3.96 & 0.40 & 3.94 & 0.42 & 4.87 & $.00 *$ \\
\hline
\end{tabular}

* Statistically significant at .05

A Comparison of Expectations and Perceptions to service in Udon Thani hospital have different statistically significant at the .05 level. When viewing the results of the analysis found that Expectations and perceptions on the services of Udon Thani Hospital are different in three aspects: tangibles, Assurance and Empathy. Except, expectation and perception of services of Udon Thani hospital side Reliability and Responsiveness not different.

\section{Discussion of Results}

From the study Expectations of Service Recipients toward the Service of Udon Thani Hospital. It was found that the clients had high expectations. Johnson \& Lyth, (1991) The expectation of service recipients for services should be based on predictable criteria. Hope comes from experiences from past experience and other experiences. Researchers have concluded that. Expectations are important for service providers or hospitals to take into account that they have full service. The thing to do is to measure good service, good value for money and if it is appreciated, it makes good. Overcoming even more expectations.

A study of perception of service recipients on the service of Udon Thani hospital. It was found that the overall perception was high. Schiffman \& Kanuk (2010) Perception is the process by which the individual chooses, processes and interprets the stimulus. And interpreted in a particular way. This means that each person will have different perceptions. From what has been the same thing. Because the interpretation of what has been may have used the knowledge or experience in the past to interpret. Each one is not equal. Therefore, the hospital will have to reassure its customers. If a client comes to the hospital for medical treatment, it must be treated properly. Be safe the opportunity to recover from illness and complete medical equipment for medical treatment. To meet the needs of customers, which will lead to customer satisfaction in the future. 
Based on the hypothesis testing, it was found that the level of expectation and level of perception of service recipients on the service of Udon Thani hospital the overall difference. Which the level of expectation is higher than the level of perception and consistent with the research of Hattaya Kaewkim (2012) The study of public health expectation and perception of quality of hospital services in Nakhon Si Thammarat. Found that overall, people had high expectations and perceived quality of service. Average score of expectation over perceived quality of service. The difference was statistically significant at the .05 level. This is because each hospital relies on a number of factors to allocate budgets to its own hospital management. However, each hospital in Thailand has different sizes. Each hospital or medical device is different. Medical personnel have are not equal. Therefore, the quality of each hospital service is not equal. Some hospitals have good quality services. Some hospitals have poor service quality. So customers will come to each hospital. There is high expectation for good service. But the service may not be as good as expected.

\section{Suggestions}

\section{Expectations Suggestions}

Customers have expectations about what is tangible and empathy. There are more expectations than the two. Udon Thani hospital should improve on what it can handle: hospitals should have state-of-the-art medical equipment and facilities to keep up with the current era and more facilities to meet the needs. In terms of empathy. Udon Thani Hospital should provide training on mental health services and practices. The medical staff are more eager to provide services. It also makes medical staff happy to work. It also helps to reduce stress in the future.

\section{Perception Suggestions}

Clients have more perceived satisfaction than expectations 1side: Assurance. Therefore, Udon Thani hospital should focus on the issue. Safety in medical treatment, availability of medical equipment and medical care. The clients pay attention to medical care, the chance of recovering from high illnesses, and the correct and complete medical treatment. However, the hospital should ensure that patients receive services through public relations regarding the treatment of diseases. To be successful, or to have new medical devices or procedures. To ensure that the service will be available to the people who will come to the service.

\section{Future Research}

This research is only an overview of the expectations of service recipients toward the service of Udon Thani hospital. In the future, should study the behavioral factors toward the service of Udon Thani hospital. It is important to note that clients who come to Udon Thani hospital have a lot of behaviors in medical treatment. To be able to refer to the research and develop Udon Thani hospital into a provincial hospital with specialized treatment. However, Udon Thani hospital will not have to send patients or patients to another hospital and will develop Udon Thani hospital to have full capacity in the future.

\section{References}

Christopher H. Lovelock. (1996). Service Marketing (3rded.). New Jersey: Prentice Hall. Hattaya Kaewkim. (2012). The Expectations and Perceptions of People toward Quality Service in Sub-District Health Promoting Hospital, Nakhon Si Thammarat Province. Master of Public Health Master Thesis Sukhothai Thammathirat Open University.

Johnson, R. \& D. Lyth. (1991). Implementing the Integration of Customer Expectations and Operational capability. Massachusetts: Lexington Book. 
Kotler, Philip. (2015). Marketing Management (Pearson Education). New Jersey: Prentice Hall.

Kotler, Philip., \& Armstrong, Gary. (2018). Principles of Marketing (17thed.). England: Pearson.

Lovelock, C., Wirtz, J. \& Chew, P. (2009). Essentials in Service Marketing. Singapore: Prentice-Hall.

National Health Development Plan Board. (2016). National Health Development Plan No. 122017 - 2021 Ministry of Public Health. Search on December 25, 2017: https://wops.moph.go.th/ops/oic/data/20161115144754_1_.pdf

Nitipol Phutachote. (2016). Marketing Services. Khon Kaen: Faculty of Business Administration and Accounting Khonkaen University.

Schiffman, L. G., \& Kanuk, L. L. (2010). Consumer behavior (10thed.). Upper Saddle River, NJ: Prentice-Hall.

Schiffman, L., \& Wisenblit, J. (2015). Consumer Behavior. Boston: Pearson Education.

Thanin Sinjaru. (2014). Research and analysis of statistical data with SPSS and AMOS (15thed.). Bangkok: R \& D Business Partnership

Udon Thani Hospital. (2017). History of Udon Thani Hospital. Search on December 25, 2017: http://www.udh.go.th/new2016/index.php/2015-10-26-02-14-20/history1

Udon Thani Hospital. (2017). Service Potential Information. Search on January 8, 2018: http://www.udh.go.th/new2016/index.php/online/data-hosp/347-preservice

Wisher, J.D. \& Corney, W.J., (2001). Comparing practices for capturing bank customer feedback - Internet versus traditional banking. Bench marking: An International Journal, 8(3), 240-250.

Zeithaml, V. A., Parasuraman, A., \& Berry, L. L. (1990). Delivering quality service: Balancing customer perceptions and expectations. New York: The Free Press. 